\title{
Pelatihan Pengembangan Aplikasi Menggunakan Mikrokontroler untuk Meningkatkan Kompetensi Siswa SMK
}

\author{
Ida Rachmaniar Sahali ${ }^{1 *}$, Faizal A. Samman ${ }^{1}$, Rhiza S. Sadjad ${ }^{1}$, Christoforus Yohannes ${ }^{2}$, \\ Gassing ${ }^{1}$, Andani Achmad ${ }^{1}$ \\ Departemen Teknik Elektro ${ }^{1}$, Departemen Teknik Informatika ${ }^{2}$, Fakultas Teknik UNHAS \\ idar@unhas.ac.id ${ }^{1 *}$
}

\begin{abstract}
Abstrak
Kegiatan pengabdian masyarakat ini bertujuan untuk membangun kemitraan dengan SMK Negeri 4 Gowa di Kecamatan Pallangga. Salah satu keahlian profesi yang sangat penting bagi siswa SMK di bidang Teknik Elektronika adalah teknik pemrograman mikrokontroler/mikroprosesor. Kemampuan tersebut dapat membantu lulusan untuk mengembangkan bakatnya, mengekspresikan dirinya dalam lomba-lomba tingkat wilayah provinsi dan nasional dan salah satu modal kecakapan untuk siap bersaing di pasar kerja. Kegiatan ini memberikan pelatihan teknik pemrograman mikrokontroler/mikroprosesor kepada para guru dan siswa. Proses persiapan pelaksanaan pelatihan dimulai dengan melakukan koordinasi dengan mitra terkait jadwal, peserta dan materi yang akan diberikan pada saat pelatihan. Tim pelaksana kemudian membuat beberapa hardware kit training dan buku panduan sebagai bahan utama pelatihan. Pelatihan dilaksanakan selama 4 (empat) hari yaitu dari tanggal 17-18 Oktober 2018 yang dikuti oleh 7-9 orang guru dan 24-25 Oktober 2018 yang diikuti 18 (orang) siswa kelas XI. Di akhir pelatihan dihibahkan 4 (empat) kit training kepada SMK Negeri 4 Gowa sebagai bahan untuk keberlanjutan program. Hasil evaluasi kegiatan melalui kuesioner yang diberikan menunjukkan sebagian besar peserta memiliki ketertarikan yang tinggi dengan mikrokontroler dan masih ingin mengikuti pelatihan pada kesempatan berikutnya. Selain itu, terdapat pula penambahan pengetahuan dan keterampilan dari mayoritas peserta pelatihan.
\end{abstract}

Kata Kunci: Produk Elektronika; Bina Sekolah; Sekolah Kejuruan; Keahlian Profesional.

\section{Pendahuluan}

\subsection{Lokasi SMK Negeri 4 Gowa}

SMK Negeri 4 Gowa sebelumnya bernama SMK Negeri 1 Pallangga berjarak kira-kira 9,2 km ke arah barat Kampus Gowa, Fakultas Teknik, UNHAS, di seberang selatan Kota Sungguminasa, Ibukota Kabupaten Gowa. Gambar 1 memperlihatkan peta lokasi sekolah mitra.

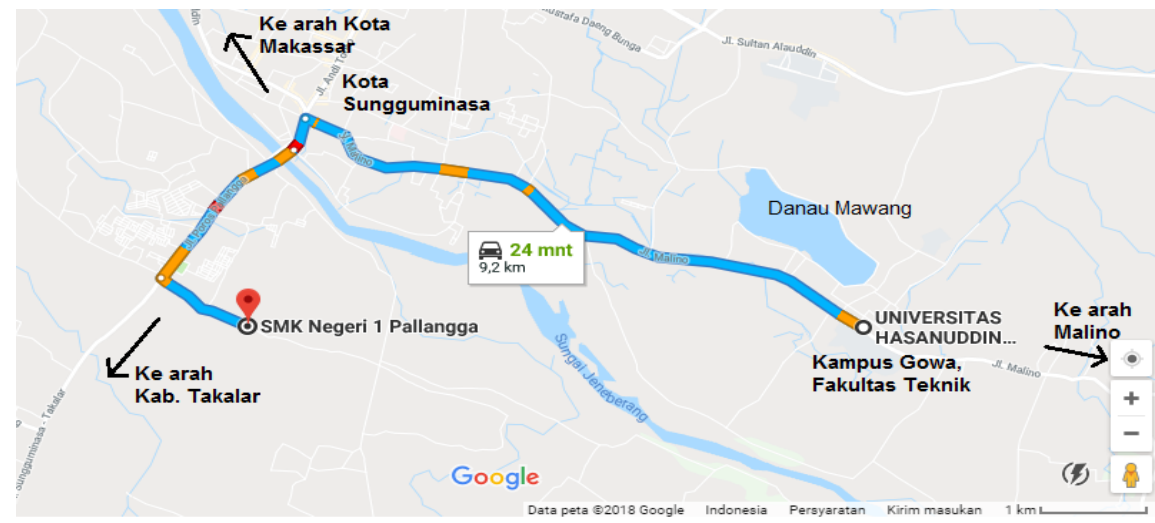

Gambar 1. Peta Lokasi Mitra SMK Negeri 4 Gowa di Kecamatan Pallangga. 
Salah satu Jurusan yang ada di SMK Negeri 4 Gowa adalah Jurusan Teknik Elektronika yang terafiliasi dalam program Teknik Audio Video. Ada 7 orang guru di bidang tersebut. Fasilitas yang dimiliki pada bengkel antara lain Osiloskop, Function Generator, Multi Tester dan beberapa peralatan bengkel. Beberapa mata pelajaran keahlian yang ditawarkan oleh Jurusan Teknik Elektronika adalah: (1) Kerja Bengkel dan Gambar Teknik, (2) Dasar Listrik dan Elektronika, (3) Teknik Pemrograman dan Mikroprosesor, (4) Rangkaian Elektronika, (5) Sistem Audio, Radio, TV dan Antena, (6) Perbaikan Peralatan Audio Video, (7) CCTV, (8) Audio Video Mobil, dan (9) Dokumentasi Audio Video.

SMK Negeri 4 Gowa pada dasarnya telah menjalankan kurikulum pendidikan dengan baik. Beberapa guru juga telah memiliki spesifikasi pendidikan yang cukup baik. Namun demikian, dari sekian permasalahan yang ada misalnya obyek eksperimen yang sudah usang seperti TV jenis tabung, guru-guru masih membutuhkan infomasi up-to-date terhadap perkembangan teknologi di bidang Elektronika khususnya mikroprosesor/mikrokontroler dan teknik pemrogramannya serta pengetahuan tambahan untuk melatih kecakapan profesional anak didiknya.

Salah satu keahlian profesi yang sangat penting bagi siswa SMK di bidang Teknik Elektronika adalah teknik pemrograman mikrokontroler/mikroprosesor. Kemampuan tersebut dapat membantu lulusan untuk mengembangkan bakatnya, mengekspresikan dirinya dalam lombalomba tingkat wilayah provinsi dan nasional dan salah satu modal kecakapan untuk siap bersaing di pasar kerja. Untuk menambah pengetahuan dan keterampilan guru terhadap teknologi terkini bidang mikroprosesor/mikrokontroler serta teknik-teknik pemrogramannya, maka Tim Kami memberikan proses transfer pengetahuan dan teknologi dalam bentuk hands-on training kepada guru-guru bidang studi Teknik Elektronika mengenai salah satu bidang penting yaitu pemrograman mikroprosesor atau mikrokontroler.

Tim kemudian menghibahkan beberapa hardware kit training yang kami buat sendiri beserta buku manual cara penggunaannya untuk disimpan di bengkel elektronika SMK Negeri 4 Gowa. Guru-guru dilatih mengenai teknik-teknik pemrograman mikroprosesor atau mikrokontroler melalui pemanfaatan hardware kit tersebut. Pemberian materi pelatihan langsung kepada guruguru ini dilakukan untuk menjamin keberlanjutan program kegiatan. Selain itu diberikan pula materi kepada sebagian siswa untuk melihat respon siswa terhadap metode pembelajaran yang dirancang.

Untuk mengevaluasi keberhasilan program yang dilaksanakan, dilakukan analisa terhadap hasil kuesioner yang diberikan ke peserta. Serta bertanya langsung kepada guru-guru beberapa bulan setelah pelatihan terkait penggunaan kit training yang telah diberikan.

\section{Latar Belakang Teori}

Sistem Kendali menurut Rhiza adalah sistem 'apa saja' yang terdiri dari 2 (dua) bagian yaitu kendalian (plant) dan pengendali (controller). Varian dari sistem kendali sangat luas dari yang sederhana berupa sistem kendali penyalaan lampu menggunakan saklar sebagai pengendali dan lampu sebagai kendalian sampai kepada pengendalian proses yang kompleks. Contoh kendalian adalah proses-proses di industri, sistem otomotif, pesawat terbang, kapal dan lain-lain. Sedangkan contoh pengendali, pengendali analog yaitu pengendali PID, Phase Lead Lag dan adapula pengendali digital seperti gerbang logika, rangkaian logika, komputer, jaringan komputer, mikrokontroler (Rhiza, 2018). 
Sedangkan mikrokontroler adalah komputer tanpa piranti antara (interface) dengan manusia, seperti monitor, keyboard, mouse. Bagian penting dari sebuah chip mikrokontroler adalah processor, memori (ROM dan RAM), unit Input dan Output serta unit tambahan (internal maupun eksternal) seperti Analog-to-Digital Converter (ADC) atau Digital-to-Analog Converter.

Arduino UNO adalah sistem komputer kecil yang dapat diprogram menggunakan intruksiintruksi untuk berinteraksi dengan berbagai macam perangkat input dan output. Arduino UNO menggunakan chip mikrokontroler ATmega328P yang memiliki 14 pin digital Input/Output, 6 input analog, isolator Kristal $16 \mathrm{MHz}$, koneksi USB, power jack, ICP header dan tombol reset (Boxal, 2013).

Gambar 2 adalah kit Arduino UNO. Terdapat beberapa kelebihan dari Arduino diantaranya tidak memerlukan perangkat chip programmer karena memiliki bootloader yang akan menangani upload program dari komputer, memiliki sarana komunikasi USB, bahasa pemrograman relatif mudah karena software Arduino dilengkapi dengan kumpulan library yang cukup lengkap, memiliki modul siap pakai (shield) yang bisa ditancapkan pada board Arduino. Misalnya shield GPS, Ethernet, SD Card (Monk, 2017).
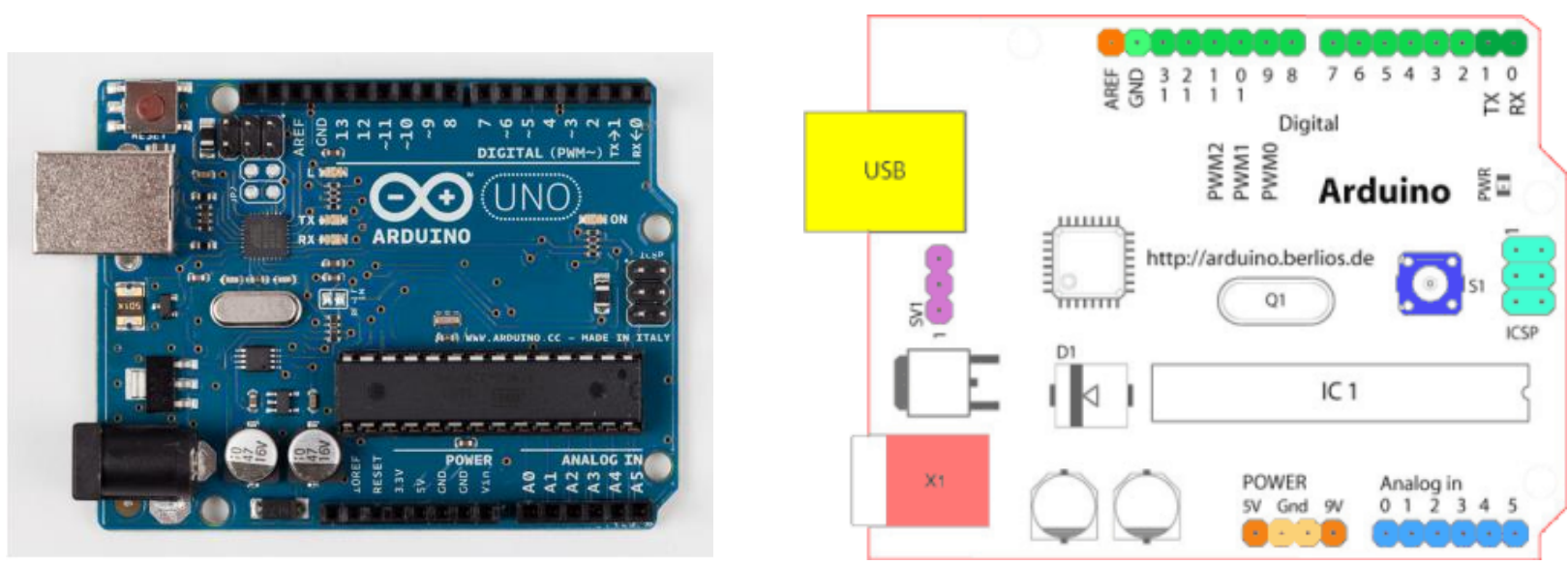

Gambar 2. Arduino Uno

Perangkat lunak yang digunakan untuk menulis, mengkompilasi dan menjalankan program untuk mikrokontroler Arduino adalah Arduino IDE (Integrated Development Environment). Software ini bersifat gratis dan dapat diunduh dari https://www.arduino.cc/en/Main/Software. Beberapa latihan program sederhana terdapat pada (Purdum, 2012). Setiap program Arduino memiliki 2 (dua) bagian utama, yaitu:

void setup() - Menyiapkan hal-hal yang harus dilakukan sekali saja.

void loop () - Berisi instruksi yang berulang-ulang dikerjakan sampai board dimatikan. 


\section{Metode}

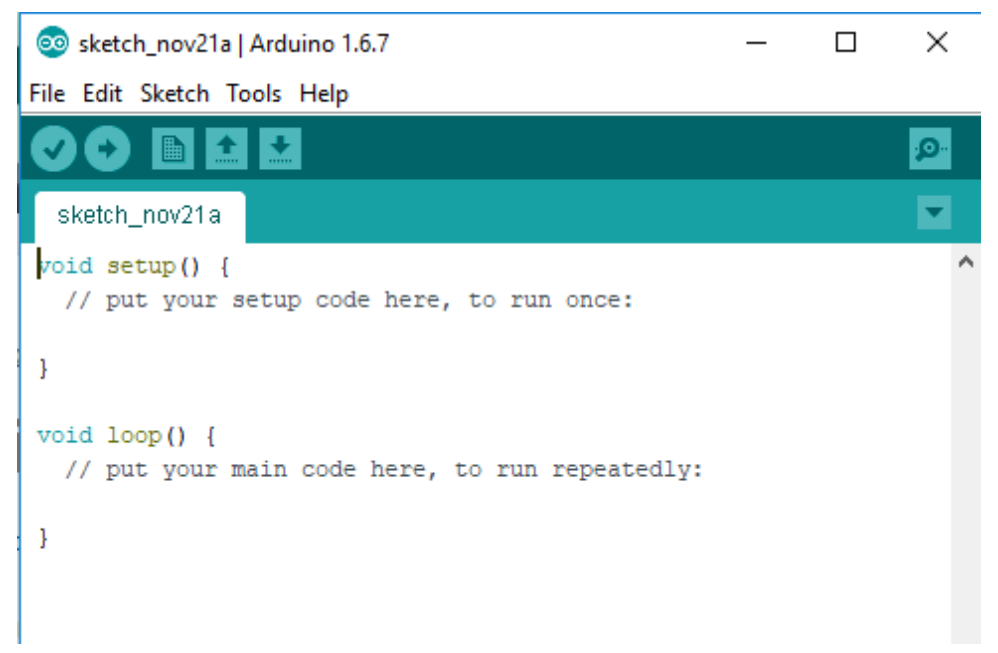

\subsection{Tahapan Kegiatan dan Metode Pendekatan}

Secara umum kegiatan ini dibagi ke dalam 3 tahap, yaitu tahap persiapan, tahap pelaksanaan dan tahap evaluasi. Gambar 4 memperlihatkan bahan alir tahapan-tahapan kegiatan tsb. Setelah tahapan evaluasi berakhir, maka hasil evaluasi akan dijadikan sebagai bahan pertimbangan untuk melakukan perbaikan-perbaikan di tahun berikutnya. Sebagaimana disebutkan sebelumnya, bahwa program pelatihan ini akan diupayakan dilakukan secara berkala untuk meng-upgrade ilmu pengetahuan guru-guru terhadap teknologi ini.

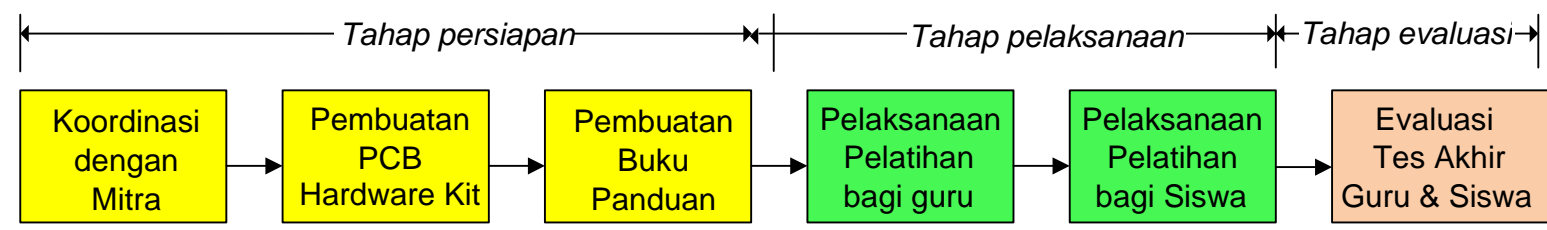

Gambar 4. Bagan alir kegiatan.

Untuk memperlancar proses transfer pengetahuan dan teknologi tersebut, Tim Pelaksana mengembangkan sendiri hardware kit training beserta buku panduan penggunaan hardware kit tersebut.

\subsection{Langkah Evaluasi Pelaksanaan Program dan Keberlanjutannya}

Sebagai langkah evaluasi terhadap keberhasilan program yang dijalankan, maka diakhir pelatihan diberikan kuesioner untuk mengukur tingkat pemahaman dan keahlian guru dan siswa 
SMK 4 Gowa dalam menguasai teknik perancangan sistem berbasis mikroprosesor setelah mengikuti pelatihan.

Untuk menjamin keberlanjutan program ini, maka di satu sisi, kami akan tetap membuka diri kepada pihak SMK untuk mengunjungi kami. Di sisi lain, pihak SMK Negeri 4 Gowa juga akan bersedia menerima kami untuk mendapatkan informasi terbaru terhadap perkembangan teknologi mikroprosesor dan mikrokontroler tersebut.

\section{Hasil dan Diskusi}

Seperti yang dijelaskan pada tahapan kegiatan dan diilustrasikan pada gambar 3, tahapan kegiatan terdiri dari 3 (tiga) fase yaitu tahap persiapan, tahap pelaksanaan dan tahap evaluasi.

Tahap persiapan terdiri dari kegiatan koordinasi dengan mitra yaitu guru yang menangani bidang kurikulum untuk mendiskusikan jadwal kegiatan, peserta pelatihan serta materi yang dibutuhkan oleh sekolah mitra. Dilanjutkan dengan perancangan dan pembuatan hardware kit serta buku panduan pelatihan.

Tahapan pelaksanaan terbagi menjadi dua bagian. Tahapan pertama adalah pelaksanaan pelatihan untuk guru yang diselenggarakan pada tanggal 17-18 Oktober 2018 yang diikuti oleh 9-11 orang Guru dari Jurusan Elektronika. Materi yang diberikan pada pelatihan ini diantaranya pengantar sistem kendali, konsep dan teknologi mikrokontroler / mikroprosesor, revolusi industry 4.0, pengantar Bahasa pemrograman, latihan pemrograman menyalakan led, membaca nilai sensor, mengatur penyalaan led melalui tombol, menampilkan tulisan pada lcd serta mengendalikan motor. Tahapan kedua pelaksanaan pelatihan untuk siswa yang diikuti oleh 18 orang siswa dari kelas XI.

Tahapan evaluasi diawali dengan pemberian kuesioner sebagai materi evaluasi pelaksanaan pelatihan. Dari isian kuesioner kemudian dibuat rekapitulasi seperti yang disajikan pada Gambar 5. Gambar tersebut menunjukkan mayoritas peserta terdapat penambahan pengetahuan dan keterampilan dari guru dan siswa setelah mengikuti pelatihan. Walaupun terdapat pula yang tetap menunjukkan bahwa ke depan materi yang diberikan perlu ditingkatkan lagi.
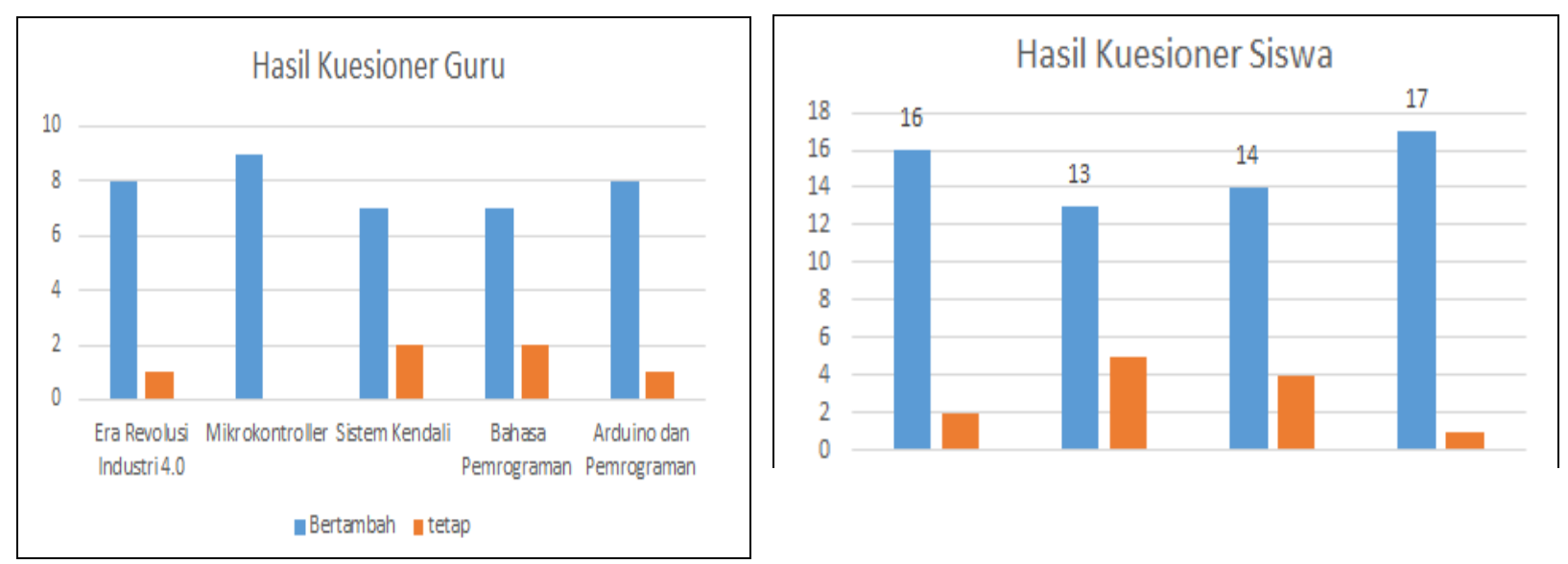

Gambar 5. Hasil Kuesioner Peningkatan Pengetahuan serta Keterampilan Guru dan Siswa 


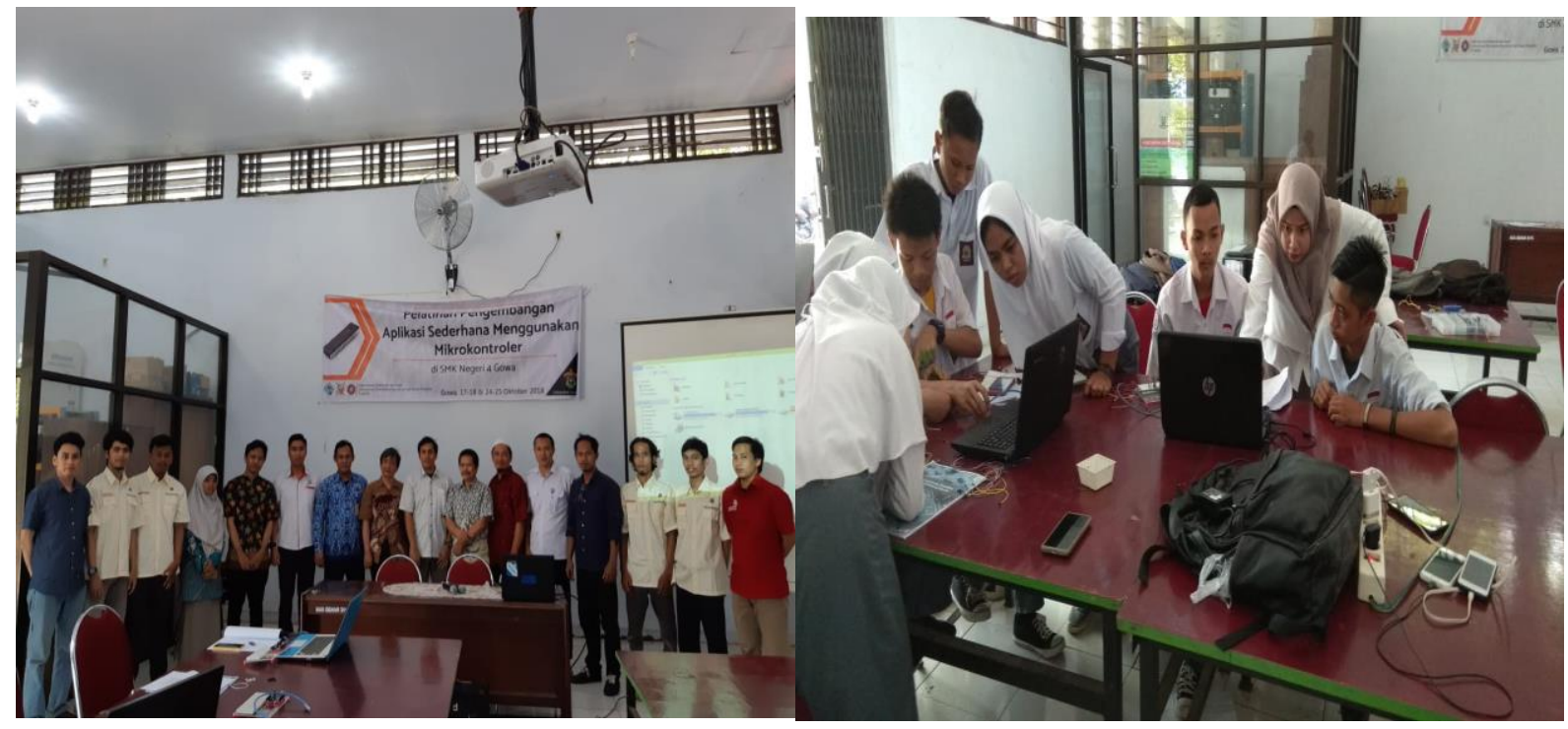

Gambar 6. Dokumentasi Kegiatan Pelatihan dengan Peserta Guru dan Siswa

\section{Kesimpulan}

Hasil evaluasi penyelenggaraan pelatihan melalui pengisian kuesioner menunjukkan tingkat pengetahuan dan keterampilan peserta tentang mikrokontroler, pemrograman mikrokontroler serta aplikasinya semakin meningkat melalui antusiasme peserta selama mengikuti proses pelatihan. Pemberian beberapa kit training kepada SMK Negeri 4 Gowa memberikan kesempatan untuk keberlanjutan program.

\section{Ucapan Terima Kasih}

Ucapan terima kasih kepada Kepala Sekolah SMK Negeri 4 Gowa beserta jajarannya yang telah memfasilitasi dan mendorong pelaksanaan kegiatan ini. Terkhusus kepada peserta baik dari pihak guru maupun siswa yang sangat antusias mengikuti pelatihan. Selain itu, ucapan terima kasih juga diberikan kepada adik-adik mahasiswa yang tergabung dalam Gugus Kegiatan Mahasiswa (GKM) Trensilica, Fakultas Teknik Universitas Hasanuddin yang telah membantu terlaksananya kegiatan. Penghargaan yang setinggi-tingginya diberikan kepada Universitas Hasanuddin melalui hibah Peningkatan Kemitraan Masyarakat telah mendukung kegiatan ini.

\section{Daftar Pustaka}

Rhiza S. Sadjad. (2018). Pengantar Sistem Kendali. Materi Pelatihan Pengembangan Aplikasi $\begin{array}{lll}\text { Sederhana } & \text { Menggunakan } & \text { Mikrokontroler. }\end{array}$ http://www.unhas.ac.id/ rhiza/arsip//jurusan/presentasi/Sistem_Kendali/Sistem_Kendali.pdf John Boxal. (2013). Arduino Workshop - A Hands-on Introduction with 65 Projects. No Starch Press, 2013. 
Simon Monk. (2017). Electronics Cookbook - Practical Electronic recipes with Arduino \& Raspberry Pi. O'Reilly, 2017.

Jack Purdum. (2012). Beginning C for Arduino - Learn C Programming for the Arduino and Compatible Microcontrolle. Technology in Action, 2012. 